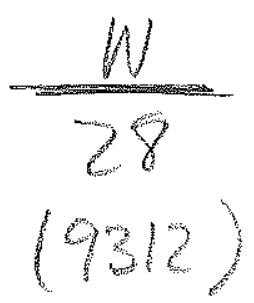

DOCUMENTO DE TRABAJO

9312

Industrial Policy in Post-socialist

Transitions: Some Lessons from the

East Asian NICs.

PABLO BUSTELO

FACULTAD DE CIENCIAS ECONOMICAS Y EMPRESARIALES - UNIVERSIDAD COMPLUTENSE Campus de Somosaguas. 28223 MADRID 
EADI 7 th GENERAI CONFERENCE

Transformation and Development: Eastern Europe and the South Berlin, 15-18 September 1993

Working Group: Changes in Europe and North-South Relations

\title{
Industrial Policy in Post-socialist Transitions: some Lessong from the East Asian NICs
}

\author{
PABLO BUSTELO* \\ Complutense University of Madrid \\ Spain
}

Second draft: July 1993

Escuela Universitaria de Estudios Empresariales

Universidad Complutense de Madrid

Plaza de España, 16

28008 Madrid (Spain)

Tel.: 1.394 .68 .13

Fax: 1.394 .67 .97

Summary: This paper contrasts Eastern Europe's current economic reforms (based on free market principles) with the experience of some East Asian countries (South Korea and Taiwan), which relied heavily since the 1960 s on import protection and government intervention. Firstly, the role of protection and government support in the Asian NICs is stressed. Their gradual financial and trade liberalizations of the $1980 \mathrm{~s}$ are also reviewed. Secondly, the main flaws of the current reforms in Eastern Europe are highlighted. The paper suggests that the experience of the East Asian NICs challenges free market reform as both a restructuring policy and a structural development strategy.

* The author gratefully acknowledges the assistance of Andrew Mold. An earlier version of this paper was presented at the DSA Industry and Trade study Group Meeting (London, July 1993).

Pablo Bustelo, Ph. D., is Associate Professor of Economics at the Complutense University of Madrid. Specialist in East Asian economies, he is author of various articles and of the books Economia politica de los nuevos palses industriales asiaticos (The Political Economy of the Asian Newly Industrializing Countries), Siglo XXI Editores, Madrid, 1990 and Economla del desarrol10. Un análisis historico (Development Economics. A Historical Analysis), Editorial Complutense, Madrid, 1991 (2nd edition, 1992). 


\section{INTRODUCTION}

The current attempt of transforming socialist economies based in state ownership and central planning into capitalist economies with private property and free markets is one of the most exciting issues of the world economy in the early $1990 \mathrm{~s}$.

Radical programs of economic reform in Eastern Europe after 1989 have relied heavily on a new orthodoxy that, on one hand, places strong emphasis on shock therapy-type macroeconomic stabilization and, on the other hand, stresses the role of free markets, thus urging rapid trade and financial liberalization, one-off privatisations and indiscriminate opening to foreign investment.

These programs may perfectly be examined in a development economics analytical framework. The new paradigm represents a sharp departure from the widespread consensus that emerged from the lessons derived from the recessive stabilization policies followed in the $1980 \mathrm{~s}$ in some Thir, world countries, such as in Latin America, and also from the previous development strategies, based on state dirigism, pursued in some successful developing economies, such as those of the Asian Newly Industrializing Countries (NICs), and from their cautious and gradual liberalization policies in the $1980 \mathrm{~s}$.

The starting point of this paper arises from a striking alternative which has been recently stated as follows:

"the Asian example poses a dilemma for bodies such as the IMF and the World Bank, specially in former communist countries. Does it still make sense to advocate a form of shock therapy - the doctrine that deregulating and 
privatising everything as fast as possible is the optimum policy? Or should they recommend East Asia's slower, more interventionist path to economic maturity?" (Prowse, 1993: 15).

This paper argues in favour of an affirmative answer to the latter question. It suggests that the experience of the East Asien NICs (South Rorea and Taiwan) challenges the theoretical basis which underpins the current free market reforms, and may even offer a model (or, at the very least, some lessons) for a successful transition in Eastern Europe. It shares the assumption of many commentators that post-socialist transition "will not be easy, will largely have to be mediated by the state and [that] r. -O-OECD forms of economic organization should be explored" (Taylor, 1992: 1) and that "useful lessons of how to do things right might come from Asia" (Fry and Nuti, 1992: 32). Furthermore, the Asian model is begining to be taken into account by politicians and economists in the transitional economies themselves: "many policy-makers $(\ldots)$ in the formerly planned economies of Eastern Europe $(. .$.$) openly say that the coexistance$ of plans and markets in East Asian capitalism can be a useful model in their transition efforts" (Lee and Lee, 1992: 108).

Firstly, foreign trade policies and the role of states and markets are reviewed in the East Asian context. The basic conclusion is that the growth performance of South Rorea and Taiwan in the 1960 s and 1970 s did not take place in a laissezfaire regime but with trade restrictions and pervasive government interventions, through managed credit and export policies, public investment, state enterprises, financial control and monitoring of foreign direct investment (FDI). Furthermore, the main features of their economic liberalization in the $1980 \mathrm{~s}$ are also highlighted, as it did not proceed in a big bang manner but 
through selective import liberalization and the gradual lifting of regulations over the financial system and FDI.

Secondly, the main effects of shock therapy in postsocialist Eastern Europe are briefly considered, since the stabilization efforts may be ill-conceived and a gradualist approach to macroeconomic imbalance correction could be much more fruitful. It is also suggested that rapid trade liberalization and the accelerated tendency towards minimal public sectors may prove to be a wrong path, as they will probably lead to acute economic and social disruptions.

The conclusions summarize the arguments and suggest that Eastern Europe policy-makers and econulists, and also western advisors, should turn their attention much more to the Asian NICs' experiences, as they may prove very useful in order to achieve an economically successful and socially balanced transition.

2. IMPORT PROTECTION AND STATE INTERVENTION IN SOUTH ROREA AND TAIWAN: A SHORT SUMMARX

As already noted, South Korea and Taiwan did not follow a liberal development strategy in the 1960 s and 1970s, contrary to the claims of neoclassical economists such as Balassa (1988) or Rrueger (1990). In the 1960s, they pursued a state-led industrialization in which private firms relied heavily on the active credit, exchange rate, export and technology policies designed and implemented by the government. Their adjustments to the 1970s' external shocks, although this issue will not be discussed here, did not involve strictly orthodox fiscal and monetary policies but were based instead on increased public investment in education and infrastructure (and even on heavy and chemical industries in the case of korea) and low interest rates. 
Furthermore, their liberalization policies in the $1980 \mathrm{~s}$ followed a cautious path. After the second oil shock, monetary policy became tighter but, throughout the decade, imports were liberalized in a selective way and controls over the financial system were only lifted gradually.

\section{(a) Trade regimes and state policies}

Before reviewing the growth contribution of import protection, several preliminary aspects should be kept in mind. Firstly, the magnitude of the import liberalization process undertaken in South Korea and Taiwan in the $1960 \mathrm{~s}$ has been largely exaggerated by neoclassical ecinomists: extensive researchs have clearly shown that the tariff system remained virtually intact and that non-tariff barriers were only lightly reformed (Luedde-Neurath, 1986 and Wade, 1990, chap. 5). Secondly, the resulting average effective protection rate was certainly lower than in Latin America but not low by international standards and it presented a high sectoral dispersion, with very high rates in consumer durables, intermediate goods, machinery, and transport equipment (Weiss, 1988: 274). Thirdly, protection continued beyond the importsubstituting industrialization (ISI) phase and pervaded most of the export-oriented industrialization (EOI) period, because its negative impact was offset by massive export incentives: the result was a strategy of "export oriented import substitution", an audacious but incisive term coined by Gold (1986).

The Asian NICs provided extensive protection to domestic industries in several interesting ways that substantially departed from the experience of other Third world countries, most notably in Latin America. 
Firstly, they used protection on infant industry grounds, as did many other developing countries. What seems to be unique to the Asian NICs is that this kind of protection also served to "incubate" export sectors. During the ISI phase, South Rorea and Taiwan applied an export-import link system, under which only firms achieving export targets could obtain import licenses. Moreover, in Korea several devaluations (in 1954, 1955 and 1960) preceded the large currency depreciations undertaken in 1961 and 1964 with the launching of the EOI strategy. Furthermore, even during the ISI period, exporters were granted with incentives, such as favourable exchange rates, rebates of tariffs, preferential access to long- and short-term credit and reductions in all or almost all direct and indirect taxes (Alam, 1989: 55-6 for Taiwan and Westphal, $1990 \% 47$ for Korea).

Thus the government urged infant industries to pursue an early outward orientation. This use of protection as an "incubator" of export sectors contrasts sharply with the experience of Latin America in the 1950s, where protection acted as a powerful greenhouse under which inefficient and internationally non-competitive industries prosperci.

In the EOI period, protection was also used to enhance the competitiveness of production in world markets, through a strategy that Rrugman (1984) termed "import protection as export promotion". Import controls (often in the form of quotas that set ceilings on imports) allowed firms to impose high prices and to obtain high rates of return on their sales in the domestic market, which presented a low elasticity of demand with respect to price. This high profitability, in turn, made possible to squeeze export prices: by sheltering the non-export sales, the government enabled firms to practice discriminatory pricing on their exports and sales in the domestic market (Westphal, 1990: 47). An excellent study on South Korea's development has also 
shown that "If overseas sales were not always profitable (...), then the government compensated the losers by inflating the returns on domestic sales. It did so by imposing trade barriers on imports" (Amsden, 1989: 69-70). A good (but by no means the only) example is the Rorean automobile industry which received simultaneously protection and normal export incentives. This kind of protection could be considered as a hidden subsidy to exports (Smith, 1991: 11).

Finally, protection furthermore acted as an instrument of industrialization, that is, as a dynamic lever to diversify the industrial sector. South rorea often imposed import controls through a de facto "law of similars", under which an import license was only grafted if the firm wishing to import $\varepsilon$ specific product could demonstrate that the item was not available domestically at reasonable terms (Westphal, 1990: 47). The government also imposed local-content rules in order to require specific industries to procure a growing share of their inputs from domestic producers (Pack and Westphal, 1986: 95). Moreover, export incentives were increasingly extended to indirect exporters, that is, manufacturers of intermediate and capital goods used in the production of consumer durables for the world markets. In the 1970s, the Rorean government introduced additional import restrictions on intermediate and capital goods in order to deepen this substitution process.

In short, the Asian NICs used protection as an industrialization "tool", so as to foster the internal backward linkages of the consumer durables' dynamic export sector. Most other developing countries, such as those in Latin America, considered export industries merely as a foreign exchange source, primarily in order to finance the imports required by the prolongation and deepening of ISI and also to service the foreign debt. 
Turning now to the role of the state, it should be remembered that what Albert Hirschman termed late-late industrialization processes (Hirschman, 1968: 8-9), like those of South Korea and Taiwan, have proceeded without technological innovations (that is, they have been characterized by the absence of pioneering technologies). Instead they have been based on learning, so development has tended to be guided, much more than in Gerschenkronian cases of lete-industrialization (Germany, Italy, Russia...), by industrial and technological policies (Amsden, 1991 and $1992 \mathrm{~b}$ ). Contrary to neoclassical claims, the role of government in the East Asian NICs has not been detrimental to growth. Rather it has clearly facilitated it. Several studies have. convincingly stressed the importance of government intervention, although two versions of this approach may be distinguished: for some analysts, the role of the state has been market-sustaining, as it has "governed the market" (Wade, 1990); others argue instead that public intervention has been directed to deliberately distort relative prices in a determined way and that this kind of distorsion has bepn conducive to high growth (Amsden, 1989). Although more discussion over these contrasting views is surely needed, the existence of distorted prices of both factors and goods tends, in my view, to confirm Amsden's approach: explaining growth by low wages through repressive labor market policies, low interest rates due to preferential access to credit, high prices in the domestic market as result of protection and low export prices because of the previously noted price discrimination and of massive export incentives.

In both South Korea and Taiwan, the government was able to influence both directly or indirectly the pattern of growth among industries and the investment decisions of the private sector and 
even to create new actors (for example, the chaebol in Korea) to undertake targeted iniciatives (Lee and Lee, 1992: 120).

Several aspects of state intervention should be kept in mind. Firstly, the state-owned or state-controlled banking sector allowed the government to subsidize targeted industrial activities. Preferential loans stimulated high levels of investment, which were considered necessary to import capital goods and to enhance efficiency. This financial control, through directed credit allocation, enabled the state to influence the financial ability of firms and to require their compliance in other matters, because of their high debt-equity ratios (Lee and Lee, 1992: 118). As Amsden has pointed out, "[in south Korea] the state used its powers to dixcipline not just workers but the owners and managers of capital as well" (Amsden, 1989: 64).

Secondly, a system of massive export incentives managed to avoid the anti-export bias that was a feature of most Latin American countries in the 1960 s and 1970s, while they were deepening their import-substitution policies. But it also even more than offset the negative impact of protection on outwardoriented production, creating a new bias as the effective exchange rate for exports was driven up to surpass the rate for imports. According to several specialists, South Korea and Taiwan were "trade-biased economies" (Fransman, 1984) with "export-push regimes" (Bradford, 1990). The export incentives are well known (Rhee, 1985): favourable import conditions (export firms had privileged access to import licenses and intermediate inputs and capital goods used in export production could be imported without tariffs); fiscal advantages (exemptions from indirect taxes and direct taxes reductions); preferential exchange rates and access to working capital borrowing for exporters, etc.. 
Thirdly, unlike Latin America, FDI monitoring was extremely successful $a$ it avoided denationalization and enhanced technology transfer from foreign firms. As Mardon (1990) has clearly stated, South korea has tended to view foreign loans as a more desirable form of foreign capital penetration then FDI and hes prefered joint-ventures to wholly-owned subsidiaries. The government approved foreign ownership levels exceeding 50 percent only if the subsidiary produced exclusively for the export market or the parent company agreed to transfer advanced technology. As a result, FDI's share of gross domestic capital formation was in 1990 substantially lower in South Korea ( 0.8 per cent) than in Brazil ( 1.3 percent) or Mexico ( 5.6 per cent) (World Bank, 1992: Table E.3).

Fourthly, technology policies were conducive to substantial improvements in the economy. The development strategy relied heavily on borrowing advanced technologies to enhance competitiveness and growth. This policy was also pursued in several other developing countries. What seems to be unique to the Asian NICs is that they relied less than other economies on formal mechanisms of technology transfer (FDI and licenses) and more on informal mechanisms (such as the import of capital goods embodying new technologies, turnkey plants, and reverse engineering). Another difference is that the import of disembodied technologies was centralized in the hands of the state, thus allowing the bureaucracy to find the most suitable and cheapest technology and to foster the bargaining position of the recipient, for instance trading market access for favourable terms in the transfer (Kim and Dahlman, 1992 and Enos and Park, $1988)$.

Finally, in the case of Taiwan the government was able to influence the small and medium private firms' decisions through their linkages with the large-scale enterprises, which have been 
until very recently state-owned. Taiwan presented in the $1950 \mathrm{~s}$ and the $1960 \mathrm{~s}$ the biggest public sector in the world outside the centrally planned economies and sub-Saharan Africa: the public enterprise share of menufacturing production was 56 per cent in 1952 and 44 per cent in 1960 (Wade, 1990: 88). Thus, in Taiwan, although direct intervention through credit control was somewhat less important than in South Korea, the state-owned enterprises allowed the government to influence microeconomic decisions in the private sector.

(b) Gradual liberalization in the 1980 s

Mckinnon (19918) has persuasively argued, on theoretical and empirical grounds, for an adecuatu. sequencing of reforms: macroeconomic stabilization should be attained before implementing trade liberalization and financial liberalization should proceed afterwards (see also Wade, 1990: 368). Moreover, Mckinnon also suggests that instant or big bang reforms (rapid stabilization, liberalization and ownership changes) could easily misfire.

The liberalization experiences of the Asian NICs in the 1980 s tend to support Mckinnon's posture. In South korea, "imports were liberalized in a selective way and regulations over the financial system (...) lifted gradually" (Solimano, 1992: 33).

Concerning trade liberalization, South Korea and Taiwan did not extensively liberalized their imports in the 1980B. Although pressure from the United States, whose bilateral trade deficits with the four Asian NICs (South Korea, Taiwan, hong Kong and singapore) reached a quarter of its global deficit in 1987, imposed, along with currency appreciation, some kind of trade liberalization, this was not accomplished in an indiscriminate 
fashion and was only carried out after attaining macroeconomic stability, contrary to the experience of most Latin American countries during the decade.

In Korea, the liberalization of imports involved mainly the easing of the discretionary import licensing scheme (Rim, 1990). Relatively high tariffs and other safeguards were maintained. Furthermore, the process allowed for the postponement of real import liberalization where firms found themselves in trouble in adjusting to the new conditions. A recent study has concluded that it was a "gradual liberalization over a number of years according to a preannounced, phased timetable" (Young, 1992: 200).

Turning now to financial liberalization, it should be kept in mind that the South Rorean government, although it privatised most banks in the early 1980s, remained often the biggest shareholder and maintained effective control over the banking institutions through its personnel policies (Lee and Lee, 1992: 117). Moreover, Amsden and Euh (1993) have argued that the freeing of interest rates was not general. Preferential access to credit for specific groups of borrowers has continued: all financial institutions, including foreign banks, were required to keep a certain portion of their loans for small- and mediumsize enterprises; export financing continued to be regulated by the central bank, under government direction (Westphal, 1990: 44$5)$. In the 1980s, the government provided attractive opportunities to savers not so much by freeing interest rates and rather by an alternative route - the stock market. It continued to lower the cost of capital to investors by developing plant sites, providing tax breaks for $R \& D$ and financing joint ventures in $R \& D$ between government and business. It developed highly regulated nonbank financial institutions, imposed tight controls on capital exports (since the current account balance 
returned to deficit in 1989) and subjected the amount of foreign capital invested in the stock market to a ceiling (Amsden and Euh, 1993).

\section{POST-SOCIALIST TRANSITIONS IN EASTERN EUROPE: SOME CAUTIONARY NOTES}

Post-socialist transitions in Eastern Europe in the late 19805 and early $1990 s$ have been probably the most ambitious attempts of economic reform in modern times. Since from the outset they have been suffering from enormous macroeconomic imbalances (high inflation rates and large public and current account deficits), at odds with the situation in, for example, pre-1979 china, the reform process should necessarily iavolve some kind of stabilization. Furthermore, structural reforms (economic liberalization and ownership changes) should also form necessary elements of the reform package.

It should be remembered, however, that the extent of stabilization and structural reform is a highly controversial matter. There is certainly scope for extensive argument about the adecuate degree and proper sequencing of those measures (Hughes and Hare, 1992: 83).

\section{(a) Stapilization}

The shock therapy-type stabilization in Eastern Europe has been proposed, and even extensively applied, as the only mean of confronting the enormous macroeconomic imbalances. Price reform, demand contraction and currency devaluation are the main ingredients of the stabilization packages started in Poland, Romania, and former Yugoslavia in 1990 and in Bulgaria and the former CSFR in 1991 (Fry and Nuti, 1992: 30). 
14

Price liberalization has often led to an initial inflationary outburst, to large cuts in real wages and, consequently, to a depressed demand of consumer goods. Together with the effective demand contraction (tight monetary and fiscal policies), which has resulted in a fall in capital formation, this has been conducive to a protracted slump in economic activity and growth. The cumulative percentage fall in industrial production in 1990-92 has been 54 per cent in Bulgaria and Romania, 40 percent in Czechoslovaquia and 32 per cent in Hungary and Poland (The Economist, 1993: 9).

Moreover, the initial currency devaluation has exacerbated inflation, as it increased import prices of machinery and technology, and has obliged the use of a fixed exchange rate as an antiinflationary device.

The result of this big bang-type stabilization has not only been a sharp recession, but also the threat that the squeeze in living standards may lead to an erosion of the socio-political support to reforms and even to some kind of dramatic policy reversal.

In view of these developments, a more gradualist approach to stabilization would appear to be urgently needed (Solimano, 1992).

\section{(b) Structural reforms}

It should be noted that a trade liberalization undertaken too rapidly may involve several negative side effects (Solimano, 1992: 6 and 29; Taylor, 1992: 15):

- a reduction in fiscal revenues in a context of high public deficits. The fall in government revenue, caused by privatization in agriculture and a decline in profitability of state-owned 
enterprises, is accompanied by a rise in government spending, in spite of tight fiscal policies and the reduction in product subsidies following price liberalization, because of increasing financial incentives to private manufacturing and the creation of a safety net for the newly unemployed. To control public deficits, the building of institutional structures to collect taxes, along lines suggested by McRinnon (1991b), should have been made before trade liberalization;

- a shift in domestic demand towards imports, exacerbated by the fall in domestic output. Together with the reduction in local spending power that follows a devaluation in presence of trade deficits (in the sense that devaluation raises exporters gains less than importers costs) (Taylor, 1993: 581), this has created recessionary results. All this has transpireo in the context of an important external trade shock (the termination of Comecon, the former Eastern bloc trade organisation, which in 1989 took 70-80 percent of many countries' exports). At the same time, a growth of exports to western markets is unlikely, because of quality problems and/or increased protectionism in EC markets. The flood of new goods into domestic markets may also reduce national savings rates and thus limit the possibility of financing public deficits in a non-inflationary manner;

- a squeeze in foreign exchange, which reduces the import capacity and thus the possibility of buying foreign capital goods. Furthermore, the use of a fixed exchange rate as an antiinflationary device tends to price exporters out of world markets. The import capacity is then unable to rise. What is more, the Argentinian and Chilean experiences of freezing the exchange rate in the late $1970 \mathrm{~s}$ furthermore suggests that this policy may ultimately lead to unsustainable trade deficits and to massive capital flight, in anticipation of a maxi-devaluation that will surely follow (Taylor, 1993: 581). Savers will move their savings abroad, even if capital flight is nominally prohibited, through overinvoicing imports and underinvoicing 
exports, that is, transfer pricing. So a managed crawling peg, with the domestic currency linked to some foreign currencies basket, may be a more appropriate policy (Fry and Nuti, 1992: 28).

Turning now to privatizations, the radical approach emphasizes the need for the state to quickly sell loss-making big enterprises. This measure may, when foreign or local buyers are found, reduce the burden on public finance. According to this approach, shares in state-owned enterprises had been distributed widely to all citizens in several Eastern European countries, as in former Czechoslovaquia and Russia in 1992. This instantaneous people's capitalism could perfectly misfire, as it doesn't resolve the probem of management. What is more, if shares are too widely-dispersed the decision-making process may even become an important problem. Privatization also eliminates potential sources of government revenue. A more gradualist approach, along the lines suggested by Kornai (1990) and Mckinnon (1992) may be more appropriate. The creation of small-scale capitalism should be encouraged before large-scale privatizations, while the latter process should be gradual, recognizing the implicit ownership rights of employees, pension funds and banks holding debts and maintaining the government as the dominant shareholder (Mckinnon, 1992: 35 ).

On the other hand, the support of loss-making public enterprises has been conducive to low interest rates, which have accelerated inflation. Raising the attractiveness of deposit money, in order to curb inflation, avoid capital flight and facilitate a non-inflationary deficit financing, may be necessary. The impact of this measure on private enterprises could be compensated by eliminating temporarily the taxation on profits generated within domestically-owned enterprises in the liberalized sector (Mckinnon, 1991b: 114). Furthermore, 
unregulated and premature financial liberalization, in the absence of a competitive banking system and prudential regulation and supervision and without a prior macroeconomic stability, may lead to acute financial crises, as was the case in several latin American countries (Mckinnon, 1989). The Southern Cone experiments have demonstrated that these crises may result in major regressive redistributions of income and wealth, as can be seen in the chilean case after 1982: massive subsidies to bankrupt banks and debtors imposed a sharp cut in social and infrastructure spending (Solimano, 1992: 9).

\section{CONCLUSIONS}

Free trade is not always conducive to high growth. The experience of the Asian NICs has shown that protection may be justified, but only if import barriers are erected to fulfil several objectives in a developmental strategy. South Rorea and Taiwan used protection as an "incubator" of export sectors, as a mechanism to enhance external competitiveness and as a lever to diversify the industrial structure. This protectionist path has proved to be very successful. On the other hand, the use of protection in order to simply insulate domestic industry from the world economy, as in Latin America between 1950-80, has proved to be inadecuate. And, of course, the indiscriminate import liberalization applied in most Latin American countries in the 1980 s was conducive to a "lost decade", in which per capita income declined.

Moreover, it is certain that the collapse of the centrally planned economies of Eastern Europe has shown that markets are necessary for sustained economic growth and development. Nevertheless, the experiences of the Asian NICs, together with those of some developed countries, such as Japan or Germany, suggest that markets are not a sufficient condition for achieving 
these goals: state intervention is also needed. This conclusion also arises from the failures of neoliberal experiments in the Southern Cone of Latin America in the late 1970 s and even from their equivalents in some developed countries, such as the United Ringdom under Thatcher. Moreover, in the depth of a recession like the present one, we should not be too confident on the superiority of the market mechanism.

Furthermore, the sequencing and degree of economic liberalization have proved to be extremely important. The East Asian NICs followed a predetermined path of liberalizations. They did not initiate them until they had managed to attain macroeconomic stability, and liberalization of the trade regime preceded the deregulation of the financial system. Furthermore, as has been suggested, the trade and financial liberalizations that South Korea and Taiwan undertook in the 1980 s were cautious: import restrictions (specially for high-technology imports) were maintained and the financial system remained fundamentally repressed, although less than in the previous period.

Thus, "East Asia's stellar growth performance, in conjunction with their ambiguous liberalization record and extensive use of industrial policy, concretely challenge free market reform as a structural development strategy" (Amsden, 1992a: 2)

Thus the post-socialist governments in Eastern Europe since 1990 may prove then to have chosen a wrong path. The negative impact of shock therapy-type stabilizations has been discussed above. Moreover, the premature trade and financial liberalizations, undertaken before attaining macroeconomic stability and building an efficient tax system, may have the same inconveniences that they featured in the Southern cone of Latin America in the 1970s: rising budget deficits (Hungary's was 7 per 
cent and Poland's 5 per cent of gross domestic product in 1992 and are likely to rise to 11 and 10 per cent, respectively, in 1993) (The Economist, 1993: 15); a shift in domestic demand towards imports; a squeeze in foreign exchange; capital flight; financial crises; regressive redistributions of wealth and $s 0$ on.

It should also be noted that the current liberal reforms may be conducive to political radicalism. Some warnings may be necessary as the "adoption of an unmodified market economy as the goal, and its achievement by shock methods, will require authoritarian methods, not just in the short run" (Mcintyre, 1993).

It has been suggested that "Eastern Europe's current free market policies $(\ldots)$ are generally inadequate to render potentially promising manufacturing enterprises competitive in world markets" (Amsden, 1992a: 1). It is likely that the liberal path may even prove to be inadequate to deal with the wdier economic issues as well. 


\section{REFERENCES}

Alam, M. S., Governments and Markets in Economic Development Strategies. Lessons from Korea Taiwan and Japan (New York: Praeger, 1989).

Amsden, A. H., "Can Eastern Europe Compete By 'Getting the Prices Right??" Paper presented at a conference on "Economic Reform: Recent Experiences in Market and Socialist Economies" (El Escorial, Madrid: July 6-8, 1992a).

Amsden, A. H., "A Theory of Government Intervention in Late Industrialization," in $L$. Putterman and $D$. Rueschemeyer (Eds.), State and Market in Development. Synergy or Rivalfy (Boulder, CO: Lynne Rienner, 1992b), pp. 53-84.

Amsden, A. H., "Diffusion of Development: the LateIndustrializing Model and Greater East Asia," American Economic Review, Vol. 81, No. 2 (May 1991), pp. 282-6.

Amsden, A. H., Asia's Next Giant. South Korea and Late Industrialization (New York: Oxford University Press, 1989).

Amsden, A. H., and Y.-D. Euh, "South Rorea's 1980 s Financial Reforms: Good-bye Financial Repression (Maybe), Hello New Institutional Restraints," World Development, Vol. 21 , No. 3 (March 1993), pp. 379-90.

Balassa, B., "The Lessons of East Asian Development: An Overview," Economic Development and Cultural Change, vol. 36 , ne 3, supplement (1988), pp. s273-s290.

Bradford, C. I. Jr., "Policy Interventions and Markets: Development Strategies Typologies and Policy Options," in G. Gereffi and D. I. Wyman (Eds.), Manufacturing Miracles. Raths of Industrialization in Latin America and East Asia (Princeton, NJ: Princeton University Press, 1990), pp. 3251.

Economist, The, "A Survey of Eastern Europe," The Economist, March 13th 1993.

Enos, J. L., and W. H. Park, The Adoption and Diffusion of Imported Technology: The Case of Korea (London, Croom helm, 1988 ).

Fransman, M., "Explaining the success of the Asian NICs: Incentives and Technology," IDS Bulletin, Vol. 15, No. 2 $(1984), \mathrm{pp} .50-6$. 
Fry, M. J., and D. M. Nuti, "Monetary and Exchange-rate Policies During Eastern Europe's Transition: Some Lessons from Further East," Oxford Review of Economic Policy, vol. 8, No. 1 (Spring 1992), pp. 27-43.

Gold, T. B., State and Society in the Taiwan Miracle (Armonk, NY: M. E. Sharpe, 1986).

Hirschman, A. O., "The Political Economy of Import-substituting Industrialization in Latin america," The Quarterly Journal of Economies, vol. 82, No. 1 (February 1968), pp. 1-32.

Hughes, G., and P. G. Hare, "Industrial Policy and Restructuring in Eastern Europe," Oxford Review of Economic Policy, Vol. 8, No. 1 (Spring 1992), pp. 82-104.

Rim, R. S., "Import Liberalization and Its Impact in Rorea," in J. K. Kwon (Ed.), Korean Economic Development (Westport, CT: Greenwood Press, 1990), pp. 99-113.

Rim, L., and C. J. Dahlman, "Technology Policy for Industrialization: An Integrative Framework and Korea's Experience," Research Policy, Vol. 21, No. 5 (1992), pp. $437-52$.

Rornai, J., The Road to a Free Economy (New York: W. W. Norton, $1990)$.

Krueger, A. O., "Asian Trade and Growth Lessons," American Economic Review, Vol. 80, ne 2 (May 1990), pp. 108-11.

Krugman, P. R., "Import Protection as Export Promotion: International Competition in the Presence of Oligopoly and Economies of Scale," in H. Kierszowski (Ed.), Monopolistic Competition and International rade (Oxford: Clarendon Press, 1984), Pp. 180-93.

Lee, R., and H. Y. Lee, "States, Markets and Economic Development in East Asian Capitalism and Socialism, "Development Policy Review, vol. 10, No. 2 (June 1992), pp. 107-30.

Luedde-Neurath, R., Import Controls and Export-oriented Industrialization. A Reassessment of the south Korean case (Boulder, CO: Westview Press, 1986).

Mardon, R., "The State and Effective Control of Foreign Capital. The Case of South Rorea," World Politics, Vol. 43, No. 1 (October 1990), pp. 11-38. 
McIntyre, R. J., "Shock Therapy Disguised as Science," Einancial Times, March the $316 t 1993$.

Mckinnon, R. I., "Spontaneous Order on the Road Back from Socialism: An Asian Perspective," American Economic Review, Vol. 82, No. 2 (May 1992), pp. 31-6.

MCKinnon, R. I., The Order of Economic Liberalization: Financial Control in the Transition to a Market Economy (Baltimore, MA: The Johns hopkins University Press, 1991a).

McRinnon, R. I., "Financial Control in the Transition from Classical Socialism to a Market Economy," The Journal of Economic Perspectives, Vol. 5, No. 4 (Fall 1991b), pp. 10722 .

MCRinnon, R. I., "Financial Liberalization and Economic Development: A Reassessment of Interest-Rate Policies in As ia and Latin America," Oxford Review of Economic Policy, Vol. 5, No. 4 (Fall 1989), Pp. 29-54.

Pack, H. and I. E. Westphal, "Industrial Strategy and Technological Change. Theory versus Reality," Journal of Development Economics, Vol. 22, No. 2 (June 1986), Pp. 87128 .

Prowse, M., "Miracles Beyond the Free Market," Einancial Times, April the 26th 1993.

Rhee, Y. W., Hustruments for Export Policy and Administration: Lessone, from the East Asia Experience," World Bank Staff Working Paper, ne 725 (1985).

Smith, S. C., Industrial policy in Developing Countries. Reconsidering the Sources of Export-Led Growth (Washington DC: Economic Policy Institute, 1991).

Solimano, A., "Diversity in Economic Reform: A Look at the Experience in Market and Socialist Economies," Paper presented at a Conference on "Economic Reform: Recent Experiences in Market and Socialist Economies," (El Escorial, Madrid: July 6-8, 1992).

Taylor, L., "The Rocky Road to Reform: Trade, Industrial, Financial, and Agricultural Strategies," World Development, Vol. 21, No. 4 (April 1993), Pp. 577-90. 
Taylor, L., "The Post-socialist Transition from a Development Economics Point of View," Paper presented at a Conference on "Economic Reform: Recent Experiences in Market and Socialist Economies," (El Escorial, Madrid: July 6-8, $1992)$.

Wade, R., Governing the Market. Economic Theory and the Role of the state in East Asjan Industrialization (Princeton, NJ: Princeton University Press, 1990).

Wei6s, J., Industyy in Developing Countries. Theory, Policy and Evidence (London: Croom Helm, 1988).

Westphal, I. E., "Industrial Policy in an Export-propelled Economy: Lessons from South Rorea's Experience," The Journal of Economic Perspectives, Vol. 4, No. 3 (Summer 1990), pp. 41-59.

World Bank, Globsl Economic Prospects and the Developing countries 1992 (Washington DC: World Bank).

Young, S.-G., "Import Liberalization and Industrial Adjustment," in V. Corbo and $S . M$. Suh (Eds.), structural Adjustment in a Newly Industrialized Country, The Korean Experience (Baltimore, MA: The Johns hopkins University press for the World Bank, 1992), pp. 171-203. 